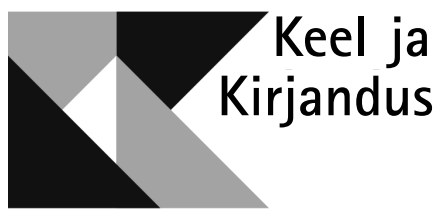

LXII AASTAKÄIK

EESTI TEADUSTE AKADEEMIA JA EESTI KIRJANIKE LIIDU AJAKIRI

\title{
SOOME DRAMATURGIA NÕUKOGUDE EESTI TEATRILAVAL
}

\author{
LUULE EPNER
}

$\mathrm{S}$

iinne artikkel käsitleb soome dramaturgia retseptsiooni eesti teatris perioodil 1944-1991 üldvaates, süvenemata eraldi ühtegi lavastusse. Otsitakse vastuseid küsimustele: milline oli soome dramaturgia lavastamise dünaamika ajas? Millised olid valikud (klassika ja kaasaegse dramaturgia vahekord, žanriline jaotus, autorid) ja mis neid mõjutas? Mis funktsiooni täitsid soome dramaturgia lavastused eesti kultuuris? Huvi pakub ka Eestis tehtud repertuaarivalikute suhestumine soome draamakaanoniga. Artikkel on üles ehitatud kronoloogiliselt - stalinismiajast pöördeajani. Alustuseks võetakse vaatluse alla teatrirepertuaari kujunemine ja seda mõjutanud tegurid Nõukogude Eestis.

Eestlasi seob soomlastega nii geograafiline ja kultuuriline lähedus kui ka Põhja-Euroopa areaalis ainulaadne soome-ugri keelesugulus. Soome pole Eestile ainult naaber, vaid ka hõimuvend, kellega on tihedalt suheldud ärkamisajast peale, nii isiklikul kui hiljem ka riiklikul tasandil - kuni unelmani Soome-Eesti kaksikriigist. ${ }^{1}$ Kujutelm, et Eesti kuulub kultuuriliselt ja poliitiliselt Põhjamaade seltsi, mis on Eesti enesekuvandis mänginud keskset rolli ärkamisajast kuni tänapäevani (vt Kuldkepp 2013), põhineb suuresti lähiseostel Soomega. Põhjamaad ning eriti just Soome on Eestile olnud positiivne väline Teine, eeskuju, millega end võrrelda ja mille poole püüelda (Petersoo

${ }^{1}$ Hea ülevaate Soome-Eesti suhteist, rõhuga XX sajandi esimesel poolel, annab Sirje Olesk (2005). 
2005: 116). Kummatigi ei tähenda see, et kahe maa kultuurisuhteid peaks vaatlema n-ö väiksema venna positsioonilt. Soome ja Eesti teatrisuhete uurimise projekt, ${ }^{2}$ mille raames valmis siinne artikkel, seab eesmärgiks uurida neid suhteid ristvalguses, s.o nii Eesti- kui ka Soome-poolsest vaatepunktist, eelistamata üht teisele.

Selle eesmärgi huvides sobib rakendada kultuuriülekande teooriat, millele panid 1980. aastail aluse Michel Espagne ja Michael Werner ning mis rõhutab suhete kahepoolsust ja -suunalisust, pakkudes alternatiivi hegemoonilisele mõjuajaloole. Kultuurivahetuse võimalikkuse eelduseks peetakse ühise aluse (pr le socle commun) olemasolu (Espagne 1999: 4), mis ühte kultuurkonda kuuluvates eesti ja soome kultuurides on lai ja tugev. Ülekanne tähendab nii materiaalsete kui ka mentaalsete kultuurielementide liikumist üle (rahvus)kultuuride vahelise piiri, kuid see ei ole mehhaaniline kandumine ühest kultuuripiirkonnast teise, vaid rõhk asetatakse taastõlgendamisele (pr réinterpretation) uues keskkonnas (Espagne 2013: 1). Kui kultuuriobjektid - näiteks näidendid - liiguvad ühest kultuurist teise, siis uues kontekstis omandavad nad uusi tähendusi, funktsioone ja positsioone laiemates kultuurisüsteemides (näiteks teatrisüsteemis), mis omakorda on taastõlgendamise protsessis aktiivne jõud. Vastuvõtva kultuuri kontekst määrab ka üldjoontes selle, mida on vajalik ja võimalik importida või mida kultuurimälust aktiveerida (Espagne 1999: 23). On jõude või tegureid, mis hõlbustavad ülekandeid ja toimivad n-ö sillana (Espagne 1999: 22), nagu näiteks Eesti ja Soome keelesugulus ning topeltidentiteediga ühisautorid (Hella Wuolijoki, Aino Kallas), aga eksisteerivad ka barjäärid ja tõkked - nõukogude ajal on oluline arvesse võtta takistusi kultuurisuhetes (nt tsensuur, nõukogude bürokraatia, füüsilise liikumise piirangud jm) ja küsida, kuidas neid ületati.

\section{Eesti ja Soome teatrisuhete ajaloost}

Enne kui liikuda artikli peateema juurde, heitkem põgus pilk Eesti ja Soome teatrisuhete ajaloole. Esimene soome näidend jõudis eesti publiku ette 1884 . aastal Vanemuises, August Wiera amatöörtrupi esituses - see oli Aleksis Kivi ühevaatuseline saatusedraama „Öö ja päev”. Soome dramaturgia lavastused sagenesid XIX ja XX sajandi vahetusest alates ning varsti hakkasid peale tekstide kahe maa vahel liikuma ka näitlejad ja lavastajad. Näiteks õppis Hilma Rantanen ära eesti keele ja töötas 1910. aastail mõnel hooajal Estonia teatris, Liina Reiman aga omandas soome keele ja mängis 1930-ndatel Soome teatrites. Iseseisvumise järel tihenes koostöö veelgi ja sai uusi vorme: mõlemal pool mängitavates lavastustes osatäitjate vahetamine, külalislavastused, teatrite võõrusetendused jne (vt lähemalt Veski 2014). Ajakirja Teater 1937. aasta maikuu number ilmus Eesti ja Soome teatri sõprusnumbrina. Juba aasta varem oli Helsingi Rahvateatri juht Eino Salmelainen, kes lavastas Estonias Hella Wuolijoe „Niskamäe naisi”, avaldanud arvamust, et eesti ja soome teater võiksid mingil moel sulanduda: „Sooviksin väga, et mõlema maa teatrikunstid

${ }^{2}$ Projekti rahastab Kone Sihtasutus (Koneen Säätiö) Soomes. 
ühenduksid nii tihedate sidemetega, et moodustaksime omaette liit-terviku maailma teatrikunsti laias riigis" (Teatriuudiseid... 1936: 295).

Kui esialgu otsis professionaliseeruv eesti teater Soomest abi, siis 1930-ndate teisel poolel oli teatrite ja teatritegijate suhtlus üsna võrdne, s.o üks pool ei domineerinud teise üle. Mis puudutab aga repertuaari, siis lavastasid Eesti teatrid sajandi esimesel poolel soome dramaturgiat märksa laiemas diapasoonis kui vastupidi: aastail 1908-1944 jõudis Soomes lavale 15 eesti näidendit ja Eestis 31 soome draamateost. 1930-ndate teisel poolel on põhjust rääkida suisa eesti-soome dominandist Eesti teatrite repertuaaris. Sel ajal olid teatris eriti populaarsed kodumaised näidendid ja dramatiseeringud (osakaal uuslavastustest 40-50\%), tõlkedramaturgias hoidsid aga esikohta soome tekstid (40 lavastuse ümber aastail 1936-1940, neist 27 Eesti-Soome ühisautori Hella Wuolijoe näidendite põhjal ${ }^{3}$ ). Sellised repertuaarieelistused on seotud nn omateatri otsingutega, mis 1930-ndatel hoo sisse said. Ka soome dramaturgiast otsiti eestlastele ja soomlastele ühist rahvuslikku omapära; keelesuguluse ja hõimusidemete tõttu oli soome teatrikultuur arusaadav ning tuttav ja sobis seetõttu kasutamiseks eesti omateatri otsingutes (vt Veski 2014: 44). Soomesuundumust tõukas tagant ka tol ajal väga aktiivne hõimuliikumine, mida toetasid Eesti, Soome ja Ungari valitsused.

Esimene hooaeg pärast Nõukogude okupatsiooni (1940-1941) ei lisanud ühtki uut soome dramaturgia lavastust, kuid mängukavas püsisid eelmise hooaja menulavastused, sh Wuolijoe, Agapetuse, Artturi Järviluoma teosed. Järjepidevus ei katkenud ka Saksa okupatsiooni ajal: aastatel 1941-1944 nägi rambivalgust ligi 20 soome näidendite uuslavastust. Kuid nõukogude võimu taaskehtestamine 1944. aasta sügisel muutis teatrisüsteemi ja repertuaaripilti põhjalikult.

\section{Repertuaari kujunemine nõukogude ajal}

Kultuuriülekannete uurimisel jääb väheks võrdlusest ja tähendusnihete kirjeldamisest. Et neid seletada, on tarvis jälgida muutuvaid ühiskondlikke ja kultuurikontekste, milles ülekanded toimuvad, nende kanaleid ja toimijaid (agente), kes etendavad protsessis aktiivset rolli. Teatri valdkonnas, mis on avalik ja kollektiivne kunstiala, on võrdlemisi lihtne kindlaks teha ja statistiliselt analüüsida kultuurivahetuse fakte, nagu näidendite tõlked ja lavastused, teatrite külalisetendused, külalislavastajate, näitlejate jt teatritegijate liikumised jms. Arvud ei hakka aga kõnelema iseenesest. Kultuurivahetust teatri alal mõjutab määravalt teatri institutsionaalsus ehk see, milliseid võimalusi avab või suleb teatrisüsteem, millises organisatsioonilises, majanduslikus, ideoloogilises raamistikus tegutsevad kirjandustoimetajad (dramaturgid), lavastajad, teatrijuhid, kes koostavad repertuaari, aga ka tõlkijad, kes vahendavad draamatekste ühest keelest ja kultuurist teise.

Sõjaeelse iseseisva Eesti ja Soome teatrid tegutsesid ligilähedastel alustel ning teatrikultuuris ei olnud silmatorkavalt suuri lahknevusi, muudkui

${ }^{3}$ Soome dramaturgiasse on siin ja edaspidi arvatud need Wuolijoe näidendid, mis on kirjutatud soome keeles. 
Soomes oli (ja on) teatreid rohkem, nii nagu elanikkegi. ${ }^{4}$ Mõlemal pool oli tegemist repertuaariteatritega, mida riik suuremal või vähemal määral rahastas. Nõukogude võim riigistas teatrid juba 1940. aastal ning allutas need parteilisele kontrollile. 1944. aasta sügisel taasalustasid tööd kõik Eesti Vabariigis tegutsenud 11 kutselist teatrit, kuid peagi hakati teatreid liitma ja sulgema, ning kui reformid 1950. aastate alguseks läbi said, oli muusikateatriks muudetud Estonia kõrval alles jäänud kõigest viis eestikeelset sõnateatrit: Tallinna Draamateater ning teatrid Tartus (Vanemuine), Pärnus, Viljandis (Ugala) ja Rakveres. Tõsi, 1952. aastal lisandus lastelavastustele spetsialiseerunud Eesti Riiklik Nukuteater. Kaks uut venekeelset teatrit artikli teema seisukohast tähtsust ei oma: 1948. aastal loodud Vene Draamateatris ei jõudnud nõukogude ajal lavale ühtki soome näidendit, kümmekond aastat (1952-1962) tegutsenud Kohtla-Järve Vene Draamateatris etendus üks, Wuolijoe „Justiina” (1960). Nõukogude ajal asutati veel kaks repertuaariteatrit: 1965. aastal Eesti NSV Riiklik Noorsooteater ja 1980. aastal komöödiale ning estraadile spetsialiseerunud Vanalinnastuudio. Rahvateatrite nimetuse all tegutsenud harrastustrupid, aga ka raadio- ja teleteater jäävad siinsest ülevaatest välja.

Soome dramaturgia esindatus sõltub võimaluste väljast - kui palju oli üldse uuslavastusi, mille sekka pääsemiseks konkureerisid soome näidendid eesti algupärandite ning teiste maade tõlkedramaturgiaga. Uuslavastuste arv vähenes Eesti Vabariigi ajaga võrreldes märkimisväärselt, mitte ainult teatrisüsteemi kokkutõmbumise, vaid ka etendamispraktikas toimunud nihete tõttu - lavastused püsisid mängukavas keskeltläbi kauem, mistõttu uusi lavastusi vajati vähem. Dünaamika on jämedais joonis niisugune: pärast teatrisüsteemi reforme langes 1950-ndateks uuslavastuste arv aastas 30-40 vahele, hakkas siis tasapisi tõusma, 1960-ndate lõpuks stabiliseerus 70 ümber (juurde oli tulnud Noorsooteater) ning kasvas 80 ligi 1980-ndatel, pärast Vanalinnastuudio loomist. Alates 1950. aastate teisest poolest loobuti repertuaariplaanide koostamisel ja kinnitamisel varasemast tavast tuua näidend lavale korraga mitmes teatris. Kui enne sõda mängiti näiteks Wuolijoe Niskamäe-tsüklit korraga üle kogu maa, siis nüüd pandi sellele piir. ${ }^{5}$ Uut praktikat näitlikustab hästi teksti valimine esimese Soomest tulnud külalislavastaja jaoks Vanemuises. Kaarel Irdi sõnavõtust kunstinõukogus saab teada, et esialgsete plaanide järgi pidi Matti Tapio lavastama Aleksis Kivi „Nõmmekingsepad”, aga kuna see tuli vahepeal lavale Tallinna Draamateatris, muutus asi mõttetuks ning Tapio võttis lavastada hoopiski Maria Jotuni „Mehe küljeluu” (Kunstinõukogu protokoll). Kui võrrelda Eesti ja Soome repertuaariuurijate (Karja 2017; Paavolainen 1992) tähelepanekuid selle kohta, missugused tegurid mõjutavad tekstide valikut, siis üks erinevus ongi mainitud lavastamispraktika: Soomes oli näidendite ringlus teatrite vahel tavaline.

Kõige tugevamaid barjääre teatrisuhetele Eestis püstitas mõistagi parteiline kontroll ja tsensuur, mida Soome teatrid ei kogenud. Nõukogude režiimi tsentraliseerituse pärast võib Nõukogude Liidu keskvõimu käsitleda kolmanda, sageli varjatud osapoolena Soome ja Eesti teatrisuhetes, kes kehtes-

${ }^{4}$ Näiteks 1927. aastal sai Soomes riigilt toetust 32 kutselist teatrit (Seppälä, Tanskanen 2010: 159).

${ }^{5}$ Üksikud paralleellavastused kahes teatris olid eranditult seotud uute eesti algupäranditega. 
tas repertuaarile ideoloogiliselt põhjendatud reeglid ja normid ning reguleeris teatrite suhtlemist lääneriikidega.

Repertuaari kujunemist Nõukogude Eestis kirjeldab Sven Karja (2017: 96-97) järgnevalt. Hooaja repertuaariplaani koostas teatri peanäitejuht koostöös lavastajate ning kirjandusala juhatajaga. Plaani kinnitas teatri kunstinõukogu, kuhu kuulus teatri loomingulisi töötajaid, teatrikriitikuid, aga ka parteifunktsionääre ja riigiametnikke, seejärel saadeti see kinnitamiseks Kultuuriministeeriumi Teatrite Valitsuse repertuaarikolleegiumile. Viimane suhtles tsensuuriorganiga (GLAVLIT-iga), kus kõik lavastamisplaani võetud tekstid tuli kinnitada, ning too suhtles omakorda tihedalt partei keskkomiteega (Viller 2015: 62). Tsensuuri eritähelepanu all olid uued eesti algupärandid ja lääne kaasaegne dramaturgia, mille esmalavastamiseks oli tarvis hankida luba Moskvast, üleliidulisest GLAVLIT-ist (Viller 2015: 63). Soome dramaturgia osas mõjutas repertuaari näiteks asjaolu, et Aino Kallase looming oli aastail 1950-1956 täielikult keelatud (Veskimägi 1996: 210, 245). Eesti GLAVLIT suleti 1990. aastal, ent poliitiline tsensuur lõppes sisuliselt 1988. aastal. Samas ei mõjutanud nõukogude aja esimesel poolel teatrite valikuid autorikaitse piirangud, sest Nõukogude Liit ühines Genfi autoriõiguse konventsiooniga alles 1973. aastal. Tsensuur koos hilisema vajadusega arvestada autoriõigusi kallutasid eelistama vana, ideoloogiliselt ohutut klassikat. Rahalised kaalutlused - vajadus teenida omatulu - mängisid Nõukogude Eestis repertuaari koostamisel aga väiksemat rolli kui Soomes, kus tähtis tegur oli teatri võimelisus võtta majanduslikke riske (Paavolainen 1992: 71). Soome näidendite võimalusi jõuda Nõukogude Eesti teatrite lavale kitsendasid omajagu repertuaari regionaalset jaotust kontrollivad kirjutamata reeglid, mille järgi lääne klassika ja kaasaegne dramaturgia võis hõivata mitte rohkem kui kolmandiku hooaja uuslavastustest (Viller 2015: 62). (See reegel hakkas jõudu kaotama 1980. aastatel.) Niisiis tekkis konkurents, kus soome näitekirjandus võistles maailmaklassika ja teiste regioonide tõlketeostega. Täpsem statistika aastate 1965-1985 kohta näitab, et tõlkedramaturgias oli ootuspäraselt ülekaalus angloameerika kirjandus (35\%) ning Põhjamaade kirjanduse osakaal lääne dramaturgia lavastustest oli 17\% (Epner 2015: 193). Põhjamaadest oli aga Soome kindlalt esikohal. Näiteks rootsi kirjandust esindasid peamiselt klassik August Strindberg ja Astrid Lindgreni lastelood, norra kirjandust klassik Henrik Ibsen, kuna nende maade uuemat dramaturgiat lavastati üliharva.

Nõukogude Eesti teatritel tuli alailma reserveerida mõni uuslavastus riiklike ja parteiliste tähtpäevade tähistamiseks. Revolutsioonide aastapäevade, parteikongresside, Lenini sünniaastapäevade jms puhused kohustuslikud lavastused põhinesid reeglina nõukogude näidenditel. Sel taustal on erandlik Wuolijoe „Põleva maa” lavastamine 1905. aasta revolutsiooni 50. aastapäevaks (Vanemuine, 1955), kuid teksti üritati ideoloogiliselt „õigemaks” kohendada. See kukkus suurejooneliselt läbi, anti vaid kaheksa etendust pooltühjadele saalidele (Kruus 1999: 105). Repertuaari mõjutasid ka üleliidulised festivalid, mis olid tavaliselt pühendatud mõne vennasvabariigi või sotsialistliku maa dramaturgiale. Soome kui nõukogudesõbraliku lääneriigiga suhtlemist Nõukogude kultuuripoliitika pigem soosis, mis võib seletada asjaolu, et hooajal 1980/81 pühendati üleliiduline festival soome dramaturgiale ning sel puhul tõid pea kõik eesti teatrid välja mõne sobiva uuslavastuse. Samuti tähistati 
soome dramaturgia najal Aleksis Kivi 150. sünniaastapäeva (1984) ja „Kalevala" aastat (1985). (Seevastu Hella Wuolijoe 100. sünniaastapäev (1986) uuslavastusi ei tekitanud.) Need sündmused seletavad suures osas soome dramaturgia lavastuste sagenemist 1980-ndatel.

Hoides meeles nõukogudeaegse repertuaaripoliitika peajooni - etteantud proportsioonid, tsensuur ja enesetsensuur, n-ö kohustuslike lavastuste osatähtsus -, vaadelgem järgnevalt soome dramaturgia retseptsiooni eri perioodidel.

\section{Stalinismi- ja sulaaeg: katkestus ja klassika taastulek}

Esimene sõjajärgne hooaeg 1944/45 jätkas mingil moel sõjaeelset joont. Repertuaaris andis tooni eesti klassika ning väikelinnateatrites seati lavale Wuolijoe näidendeid, mida suuremad teatrid olid mänginud juba enne sõda: Võru Kandles ja Valga teatris Säde komöödia „Vastumürk” ning Rakvere teatris „Juuraku Hulda”. Sel ajal ei kuulunud need teosed veel kaanonisse, vaid esindasid kaasaegset kirjandust: „Juuraku Hulda” oli valminud 1937. ja „Vastumürk" 1939. aastal. Kuid taoline ,järeleesti aeg" ei saanud teatris kesta kaua. 1946. aasta augustis anti välja üleliiduline parteiotsus „Draamateatrite repertuaarist ja selle parandamise abinõudest”, milles nõuti, et teatrid mängiksid rohkem nõukogude näidendeid (Draamateatrite... 1946). Hooajal 1945/46 hõlmasidki need ligi poole ja järgmisel hooajal lausa kaks kolmandikku teatri uuslavastustest. Eesti klassika taandus uute eesti nõukogude näidendite ees (August Jakobson, Aadu Hint jt). Lääne dramaturgia nišš kitsenes 1950. aastateks ühe lavastuseni teatri kohta aastas, milleks tavaliselt valiti ideoloogiliselt ohutu maailmaklassika, ning vabanenud ruumi täitsid nõukogulikud propagandanäidendid ja sobilik vene klassika (Aleksandr Ostrovski, Maksim Gorki jmt). Kiiresti muutuvas teatripildis vilksatab üks soome dramaturgia lavastus - Teuvo Pakkala „Parvepoisid” 1948. aastal Rakveres - ja siis saabub pikk paus kuni aastani $1955{ }^{6}$

„Parvepoiste” lavastuse lugu toob esile vastuvõtumustrid, mis stalinismiajal välja kujunesid. 1899. aastal esmalavastatud laulumäng Oskari Merikanto muusikaga on tänu parvepoisiromantikale, elurõõmule ja naljale saanud Soome mängituimaks näidendiks (Laitinen 1994: 199) ning kindlustanud endale koha teatrikaanonis. Eesti teatris jääb „Parvepoisid” lavastuste arvult (seni 18) napilt maha Aleksis Kivi komöödiast „Nõmmekingsepad” (19 lavastust), kõnealune lavastus Rakveres oli järjekorras viieteistkümnes. Pakkala laulumäng oli Eestis hästi kodunenud; lavastaja Eduard Türk nimetab seda oma mälestusteraamatus tüsedaks rahvalikuks näidendiks, mis vaatamata soomelikule omapärale annab klassikalise komöödia mõõdu välja. Kuid juurutatava nõukogude ideoloogiaga tekkis ikkagi hõõrumist. Kriitikas heideti ette, et tagaplaanile on jäänud töö, mis nõukogude korra juures olla igaühele endastmõistetav, ning parvepoisid ei tee muud, kui „käivad mööda küla ringi, pillid kaenlas, ning lõbutsevad”. (Türk 1964: 387-388) Selline vulgaarmarksistlik

${ }^{6}$ Veel pikem oli paus soome kirjanduse tõlkimisel eesti keelde: tühik haigutab aastate 1942 ja 1955 vahel, kusjuures mõlemal nimetatud aastal ilmus Kivi „Seitsme venna” kordustrükk. 
etteheide reedab ka stalinismiajale omast tõrjuvat suhtumist meelelahutuslikkusesse ja koomikasse. „Parvepoiste” menu (umbes 12000 vaatajat) ja piletitulu ületasid aga operette, mis olid tavaliselt publikumagnetiks.

Soome dramaturgia ilmus taas mängukavasse 1955. aastal, kui käes oli nn sulaaeg. Repertuaar muutus mitmekesisemaks ja lääne autorite ning tekstide osakaal pööras tõusule. Põhirõhk langes siiski eesti omanäidenditele, mille seadsid prioriteediks (etteantud reeglistiku raames) nii Kaarel Ird, kes naasis Vanemuise juhi kohale 1955. aastal, kui ka Tallinna Draamateatri juht Ilmar Tammur (juhtis teatrit 1952-1970). Väga selgesti oli omadramaturgiale suunatud teatripubliku huvi: perioodil 1955-1965 vaatas neid lavastusi 45\% publikust, mis on märksa rohkem kui 29\% perioodil 1944-1955 (Kask 1987: 462). ${ }^{7}$ Hõimurahva palju mängitud, tuttavad komöödiad ja draamad sobisid rahvuslik-rahvaliku suunitlusega hästi ning meeldisid ka publikule.

Mida mängiti? Kõigepealt taastati kontakt populaarse soome klassikaga. Ridamisi tulid lavale Kivi „Seitse venda” (1956) ja „Nõmmekingsepad” (1960, mõlemad Draamateatris), jälle Pakkala „Parvepoisid” (1956, Vanemuises) ning kolm Wuolijoe näidendit, mis nüüd olid juba nihkumas kanoniseeritud klassika valda: Pärnu teatris „Juuraku Hulda” (1956) ning „Justiina” (1960, samal aastal ka lavastus vene teatris, nagu eespool mainitud) ja revolutsioonidraama „Põlev maa” Draamateatris (1955). Soome külalislavastaja Matti Tapio režiis lisandus Maria Jotuni rahvalik komöödia „Mehe küljeluu” (1961). Jotuni on üks soome teatrikaanoni põhiautoreid ja 1914. aastal kirjutatud „Mehe küljeluu” on tema esimene komöödia, mis on Soomes olnud väga menukas. Kõigil nimetatud näidendeil oli võrdlemisi pikk lavastuste slepp iseseisva Eesti ajast.

Järgnes aga jälle paus (1962-1966). Kui teha väike vahekokkuvõte 1966. aasta seisuga, mil nõukogude režiim oli kestnud juba 23 aastat (pool kogu perioodist!), siis on soome dramaturgia pilt hõre nii arvuliselt kui ka autorite ja tekstide poolest: lavastusi kokku 13, tekstid eranditult kirjutatud enne 1944. aastat ja varemgi Eesti teatrites rambivalgust näinud. Populaarseim autor on Wuolijoki (8 lavastust), paraja vahega järgnevad Kivi (2), Pakkala (2) ja Jotuni (1). Kõnekas on žanripilt: pooled lavastustest liigituvad komöödia ja rahvatüki žanri ehk meelelahutuslikku repertuaari ning neile kuulus ka publiku poolehoid. Karin Kask on koostanud perioodi 1944-1965 kohta teatrite kaupa külastatavuse edetabelid (Kask 1987: 463-464): soome dramaturgia lavastustest on esikümnes viis, sealhulgas mõlemad „Parvepoisid”. ${ }^{8}$ Kas eesti teatrite niivõrd konservatiivseid valikuid tingis mõttelaiskus või ehk kerge menu iha? Neid põhjusi täielikult välistamata võib leida muidki seletusi.

Ettekirjutatud proportsioonidega repertuaaris aitas eesti kaasaegne draama täita rubriiki „nõukogude näidend”, kuid klassikale jäi ruumi vähem, kui teatrid soovinuks - arvestades mitte ainult publiku eelistusi, vaid ka rahvuskultuuri väärtustamise ja hoidmise vajadust. 1950. ning ositi 1960 . aastatelgi toimisid klassikalavastused üksiti teatrikultuuri kaitsemehhanis-

${ }^{7}$ Aastatel $1965-1975$ oli eesti dramaturgia vaatajaid juba 51\% publiku koguarvust (Kask, Vellerand 1980: 17).

${ }^{8}$ Epp Kaidu lavastatud „Parvepoisid” Vanemuises (1956) on üks populaarsemaid soome ainese lavastusi kogu nõukogude aja ulatuses. Seda mängiti ka ringreisidel ja vabaõhuetendustena, nii et vaatajaid kogunes umbes 80000 (Ird 1982: 46). 
mina, sidudes kaasaja teatri iseseisva Eesti teatritraditsiooniga. Omaklassika kõrvale sobisid väga hästi kultuuriliselt lähedase hõimurahva tuntud teosed, mille ümber hõljus tänu Eesti iseseisvuse aega tagasiulatuvale lavastamistraditsioonile nostalgiline aura. Vahest laiendasid-täiendasid Kivi, Pakkala, Jotuni teoste lavastused rahvalik-rahvuslikku ala teatrite repertuaaris, mida peamiselt täitsid eesti klassika tähtteoste (Tammsaare, Luts) lavastused. Mis puudutab Wuolijoke, siis peituvad populaarsuse põhjused osalt tema eesti juurtes - ta oli rohkem „oma” kui mõni teine soome kirjanik. Vähetähtis pole ka see, et Wuolijoe näidendid täitsid nii 1930-ndatel kui ka 1950-ndatel sama funktsiooni mis Soomeski: pakkusid samastumisvõimalusi tugeva naisega, kes valitseb oma elu üle, võtab saatuse enda kätesse (vt Paavolainen 1992: 213-214). See seletab näiteks „Juuraku Hulda” ja „Justiina” edu. Eesti omadramaturgia sel ajal tugevaid naiskaraktereid eriti ei pakkunud ning naisautoreidki oli vaid mõni üksik. Niskamäe-tsükli suurtalu olustik võis aga eesti publikus äratada nostalgiat, tuues meelde 1930-ndate talukultuuri, mis nüüd oli hävitatud.

Miks katkes uuslavastuste rida 1960. aastatel viieks aastaks? Mingit välist põhjust ei paista olevat. Võimalik, et kuna populaarsed rahvatükid ja Wuolijoe draamad püsisid pikalt mängukavas, ei tekkinud tarvidust teha uusi lavastusi. Aasta 1967 muutis aga väljakujunenud mustreid: lavale jõudis esimene sõjajärgne lavastus uuema, samuti sõjajärgse soome teose põhjal. See sündmus sobib hästi perioodide piiripostiks. Teiseks piirimärgiks valin aasta 1979 enne soome dramaturgia festivali, mis repertuaarivalikuid silmanähtavalt mõjutas.

\section{0-ndate lõpp ja 1970-ndad: kaasaegse dramaturgia tulek ja klassika kaasajastamine}

1960. ja 1970. aastatel elavnes Soome ja Nõukogude Eesti kultuurisuhtlus märgatavalt. Kindlasti hõlbustas inimeste ja teatrite liikumist Tallinna ja Helsingi vahelise laevaühenduse avamine 1965. aastal, ehkki maitsi, Leningradi kaudu oli toimunud külaskäike ennegi. Teatrisuhteid soodustasid sõpruslepingud linnade vahel. 1955. aastal sõlmisid lepingu Tallinn ja Kotka, hiljem ka teatrilinnad Pärnu ja Vaasa. ${ }^{9}$ Sõpruslinnadega sai vahetada lavastajaid ning käidi ka vastamisi etendusi vaatamas ja andmas. Tallinna teatrid suhtlesid üsna elavalt Helsingi teatritega. Esimesed külalisetendused toimusid 1965. aasta kevadel, kui Tallinna Draamateater andis etendusi Helsingis, Turus, Tamperes ja Kotkas ning seejärel mängis Helsingi Rahvateater-Töölisteater Tallinnas. Teatritegijate liikumisi dokumenteeriti täpselt. Näiteks on teada, et aastail 1969-1972 käis spetsialiseeritud turismigruppidega välismaal 121 teatritegijat, neist pooled lääneriikides, millest omakorda ligi pool (48\%) olid Soome-sõidud (Ülevaade... 1973: 12). Eesti teatrite repertuaarivalikuid mõju-

\footnotetext{
9 Tartust ja Tamperest said ametlikult sõpruslinnad 1992. aastal, aga seda valmistasid ette pikaajalised suhted Tampere teatri ja Vanemuise vahel. Suhteid sõlmisid Vanemuise juht Kaarel Ird ja Tampere poolt lavastaja ja näitleja Matti Tapio.
} 
tas pisut tihenenud otsesuhtlemine vähe, peamiselt Soome külalislavastajate eelistuste kaudu - tavaliselt seadsid nad lavale mõne soome näidendi. ${ }^{10}$

Väga oluliseks toimijaks kultuurivahetuses sai 1957. aastal loodud raamatusari Loomingu Raamatukogu. Tõlkeid soome keelest ilmus ses sarjas regulaarselt ning ehkki näidendeid nende seas polnud, said eesti lavastajad sealt ideid ja materjali.

Soome dramaturgiat vahendas kõnealuse 13 aasta jooksul 17 täis- ja kaks poollavastust. Poolena lähevad kirja Katri Vala luule tõlkevalimikust „Maa rinnal" (1959), mille Mikk Mikiver pani teatriõhtu jaoks kokku Antoine de SaintExupéry „Inimeste maaga” pealkirja all „Inimeste maal” (1972), ning Aapeli (Simo Puupponeni pseudonüüm) „Meie issanda sipelgad”, mida esitati koos Juhan Sütiste luuletusega „28. XII 1929” (1967). Seda oli varasemast selgesti enam: lavastusi aasta kohta oli nüüd 1,4 eelmise perioodi 0,6 vastu. Muidugi oli teatreidki rohkem (1965 asutati Noorsooteater), kuid huvi soome kirjanduse vastu muutus pidevaks: igal aastal (v.a 1973) esietendus mõni uuslavastus. Endiselt domineeris kodunenud klassika, ent repertuaaripilt oli mitmekesisem kui eelnenud kümnenditel. Noor näitleja Aarne Üksküla dramatiseeris kaasaja kirjandusest 1967. aastal Veikko Huovineni jutustuse „Havukkaaho mõtleja” ja lavastas selle Rakvere teatris pealkirjaga „Selle suve sinised mõtted”. See mõnusalt humoorikas lugu isevärki külafilosoofist, kes rändab mööda maad ja metsi, on ka Soomes olnud dramatiseeringuna populaarne. Samal aastal esitasid Draamateatri juures tegutsenud lavakunstistuudio õpilased õppelavastusena Aapeli „Meie issanda sipelgate” muhedaid monolooge.

Täiesti erandlik sündmus leidis aset 1969. aasta kevadel: Tallinna Draamateatris maailmaesietendus Eeva-Liisa Manneri „Põletatud oranž” Kotka Linnateatri lavastaja Väinö Lahti režiis. ${ }^{11}$ Modernistliku luuletajana tuntud Manner paigutas oma esiknäidendi tegevuse Esimese maailmasõja eelsesse aega ning keskendus noore, oma kodanliku perekonnaga kohanematu neiu ja tema meelehaigust raviva psühhiaatri suhtele. Soomes peeti poeetiliste, jaolt sürrealistlike või keelemänguliste kujundite küllast kammerlikku draamat teatrile liiga raskeks ning sisu poolest tol poliitilist teatrit soosival ajajärgul võõrastavaks teoseks, mis kaasaega ei kõnetanud (vt Seppälä, Tanskanen 2010: 257-258). Eestis seevastu said noore neiu ängistus ja mässumeelsus poliitilisi alltekste, kriitikas tõlgendati lavastust aja närvi valusalt puudutava võitlusena isiksuse vabaduse eest, kompromissituse ja kohanemise konfliktina (nt Tobro 1969; Balbat 1972). Soome näidend haakus kaasaja eesti ühiskonna vaimsete jõujoonte ja tundestruktuuridega. Ehkki samal 1969. aastal lahvatanud teatrimurranguga (Evald Hermaküla ja Jaan Toominga lavastused) oli „Põletatud oranžil” väljendusvahendites vaevalt midagi ühist, võis selles tajuda murrangu alustundeid - ängi ja võimetut raevu. Samas on huvitav märkida, et näidendi freudistlikud ideed ei leidnud laiemat kõlapinda. Neist räägiti kuluaarides, aga kuna freudism ei klappinud nõukogude ideo-

${ }^{10}$ Siiski on ka muid näiteid. Eugene O’Neilli draama „Pikk päevatee kaob öösse” jõudis Tallinna Draamateatri mängukavva tänu sellele, et Kaarina Virolainen kinkis teksti Aino Talvile Draamateatri gastrolli järel Soomes (1965). Luba mängida saadi Soomest, sealsest autoriõigusi kaitsvast agentuurist, ja see esietendus 1971. aastal (Haan, Ott 2012: 166-167).

${ }^{11}$ Soome esietendus toimus pool aastat hiljem Tamperes ning sestpeale kuulub Manneri poeetiline draama Soome teatrite püsirepertuaari (15 lavastust, lisaks ooper). 
loogiaga, siis rutati teatri eeltutvustuses kinnitama, et psühhoanalüüsi ja freudismi otsimine komplitseeritud inimsuhteid kujutavast näidendist „ei vii meid sihile" (Haan 1969).

Järgmist säärast kontakti kaasaegse soome dramaturgiaga tuli teatrivaatajal oodata üle kümne aasta. Tubli kolmveerandi uuslavastustest andis endistviisi soome klassika, ainult et varasemast veidi mitmekesisemas valikus. Aleksis Kivi (taas „Seitse venda” ja „Nõmmekingsepad”) ja järjekordse „Parvepoiste”-lavastuse kõrval väärivad mainimist Johannes Linnankoski (Vihtori Peltoneni kirjanikunimi) „Laul tulipunasest lillest” Ilmar Tammuri uues dramatiseeringus (1967) ning n-ö uus vana autor - Maiju Lassila, kelle teoseid oli varemgi saanud eesti keeles lugeda, aga teatris vaadata mitte; nüüd dramatiseeris Ingo Normet tema jutustuse „Tuletikke laenamas” (1971) ja tõi lavale komöödia „Tark neitsi” (1978). Taisto-Bertil Orsmaa, külaline Vaasast, valis lavastamiseks Maria Jotuni satiirilise komöödia „Kuldvasikas” (1979). Linnankoski, Lassila ja Jotuni nimetatud teosed pärinevad XX sajandi esimestest kümnenditest, vaid pisut uuem on Katri Vala 1920.-1930. aastail loodud luule, mida esitati eespool mainitud lavastuses „Inimeste maal”. Tegemist on niisiis ammu kanoniseeritud kirjandusega. Täpsuse huvides lisagem, et 1970-ndatel dramatiseeriti ja lavastati Nukuteatris paar soomerootsi kirjaniku Tove Janssoni 1940.-1950. aastaist pärit muumilugu, mis jäägu aga siin lähemalt vaatlemata.

Torkab silma, et hõimurahva klassikast eelistati komöödiaid ja rahvatükke, mis näib osutavat sellele, et soome huumor sobib hästi kokku eestlase meelelaadiga. Nende näidendite lavastused täitsid esmajoones meelelahutuslikku funktsiooni. Ainult Linnankoski 1905. aastal ilmunud sümbolistlike sugemetega parvepoisiromaan „Laul tulipunasest lillest” langeb sellest mustrist mõneti välja. Kai Laitineni (1994: 272) sõnul on see esimene algupärane menuk soome proosas, don Juani soome variant. Eesti poolt vaadates paistavad silma ka sarnasused August Gailiti „Toomas Nipernaadiga”. Eestis on see romantiline armastuseotsingute lugu jäänud siiski Pakkala „Parvepoiste” varju, mis rõhub rohkem koomikale.

Teatritõlgendusi vaadates hakkab silma, et kui 1950-ndatel tagas publiku soosingu sõjaeelse traditsiooni jätkamine, siis 1970-ndate menulavastused läksid kaasa teatrikunsti arengutega ning kaasajastasid klassikat märksa julgemini mitte ainult sisult, vaid ka vormilt. Nende stiil oli mängulisem ja moodsam ning vähenõudlikkugi materjali võisid vääristada leidlik režii ja säravad rollid. Pärnu teatris lavastas Ingo Normet suure eduga Lassila tekste. „Tuletikke laenamas” oli rahvatüki laadis lavastus muusikaga (vahepalu esitas kolmeliikmeline orkester viiulil ja pasunal), kus sageli oli koomika aluseks aeglustatud tempo, näitamaks soomlastele justkui igiomast pikatoimelisust ja -taibulisust (Rähesoo 2015: 577-578). Pärnu teatri kõige publikumenukam lavastus 1960.-1970. aastail (vaatajaid 85 400) oli aga „Tark neitsi”, millele Normet soomelikku ilmet ei andnud. Kriitikas tõmmati paralleele pigem laadapalagani või walt-disney'like animafilmidega (Rähesoo 2015: 587). Kujundus oli tinglik ja kostüümid mitteajaloolised; näitlejad kandsid triibulisi pükse, sabakuubi ja silindreid ning mängisid rolle bufonaadlikult. Laule-tantse, koomilisi trikke ja dialooge liitsid tervikuks populaarse ansambli Kuldne Trio laulud. (Talts 2000: 283-284) 
Nõukogude aja kõige publikumenukam soome dramaturgia tõlgendus oli Voldemar Panso lavastatud „Parvepoisid” (1975): seda laulude ja tantsudega, filmilikult dünaamilise kompositsiooniga ja jõulise näitlejatööga rahvatükki vaatas umbes 90000 inimest. Eesti teatri kontekstis nähti Panso lavastuse uudsust traditsiooni ja tinglikkust sünteesivas parvepoisiromantikas (Rebane 1976). Ka Panso „Täna mängime „Seitset venda”” (1971), teatrikooli lõpulavastus, äratas tähelepanu uudse stiilivõtmega: tänapäeva noored mängivad vana romaani lugu ja tegelasi, mängulisust varjamata. Kui seda etendati 1973. aasta kevadel Helsingis Soome teatripäevade programmis, siis hindas soome kriitika Panso tõlgenduse uueks ja värskeks.

Veidi alla kolmandiku klassikalavastustest hõivasid kahe soome-eesti ühisautori, Hella Wuolijoe ja tsensuurikeelu alt vabanenud Aino Kallase näidendid. Tõepoolest, Wuolijoe vahetult pärast sõda kaasaegsesse kirjandusse liigitatud teoseid tajuti 1970-ndatel juba klassikana. Paraku ei ergastanud nende lavastusi režii. Kui Ugalas jäeti pärast kaht lavastust („Niskamäe noorperenaine”, 1975, ja „Niskamäe Heta”, 1978) katki plaan tuua kogu Niskamäetsükkel tegevuse kronoloogia järjekorras lavale, siis huvi kadumise põhjuseks nimetati sobimatus ajajärgu moesuundadega (Kruus 1999: 220) ehk olmerealismi hülgava kujundliku režissuuriga, nagu seda praktiseerisid näiteks eespool mainitud Voldemar Panso ja Ingo Normet. Siiski olid mõlemad lavastused vaatajatele meelepärased. Võib-olla näitas nende menu laiema publiku vaimset mugavust - Wuolijoki esindas draamatüüpi, mida publik kippus „näilise turvatunde pärast ikka eelistama" (Rähesoo 2011: 190) -, kuid tõenäolisemalt mängis võtmerolli toosama nostalgiline minevikuihalus, mis tagas Wuolijoe populaarsuse eelmistel kümnenditel. Tehti ka üks põnevam katsetus: Rakveres toodi lavale Brechti ja Wuolijoe „Punttila” nn Helsingi-versioon „SuurHeikkilä peremees ja tema sulane Kalle” (1978).

Üle pika aja jõudis lavale kaks Aino Kallase teost: ajalooline draama „Mare ja ta poeg" (1970) ning varem Eestis lavastamata traagiline armastuslugu „Reigi õpetaja” Mari-Liis Küla dramatiseeringus (1976, mõlemad Draamateatris). Kui Wuolijoe teatriretseptsioon on Eestis ja Soomes olnud kaunis sarnane, siis Kallase oma mitte, erineb tekstide valik. Eestis on mitu korda lavastatud draamat „Mare ja ta poeg”, ent Soomes populaarseimat „Hundimõrsjat" on esitatud vaid korra ja sedagi kohandatult ning telelavastusena: „Legend Hundimõrsjast” Immanuel Pau dramatiseerituna (1979). Arvatavasti on põhjus selles, et libahundi teema on eesti teatris monopoliseerinud August Kitzbergi „Libahunt”.

\section{0-ndad: kaasaeg, „Kalevala”, folkloor}

Üleliidulisest soome dramaturgia festivalist kuni tsensuuri kadumiseni ehk aastail 1980-1987 tihenesid teatrikontaktid kahe maa vahel: käidi vastamisi etendusi vaatamas ning ajakirjanduses jälgiti naabermaa teatrielu pidevamalt, teatrid käisid võõrusetendustel ja külalislavastajadki liikusid sagedamini üle lahe, kusjuures eestlased tegid Soomes kaks korda rohkem lavas- 
tusi kui vastupidi. ${ }^{12}$ Ikka tugevamat orientatsiooni läände näitab muu hulgas soome dramaturgia lavastuste arvu kiire kasv: kaheksa aasta jooksul esietendus neid 18, lisaks kaks kirjanduskava, mida esitati 1984. aastal Kirjanike Maja sõnalava sildi all: soome lavastaja Väinö Lahti dokumentaalne kompositsioon „Aino Kalda ja Eino Leino lugu” ning Juhan Viidingu, Tõnis Rätsepa ja Ivo Eensalu soome vanemast proosast ja luulest koostatud „Lavakava nr 2". ${ }^{13}$ Need kavad jätan edasisest arvestusest välja. Kuid nendetagi oli keskmine lavastuste arv aasta kohta juba 2,25.

Selge nihe toimus klassika ja kaasaegse dramaturgia vahekorras: kaasaegsete näidendite lavastusi oli koguarvust kolmandik eelmise perioodi kuuendiku vastu. Päris kiiresti jõudis Eestisse ühe viljakama ja populaarsema soome näitekirjaniku Tauno Yliruusi laulumäng „Suveõhtu valss” (1982, esmalavastus Soomes 1978). See 1914. aastal ühes suvehotellis toimuv „helge, rõõmus ja žanrile kohaselt süüdimatult roosa lavalugu" (Leppik 2006: 137), milles oli romantikat, huumorit ja palju Oskar Merikanto muusikat, kogus Viljandi Ugalas tähelepanuväärselt palju publikut (58 000 vaatajat). Yliruusi lastenäidendit „Kadunud aabitsa saladus” mängiti Nukuteatris (1980). Uus komöödiateater Vanalinnastuudio kutsus Lahti teatrist lavastama Aimo Hiltuneni, kes valis Daniel Katzi komöödia „Kolme peaga Buddha” (1984, esmalavastus 1978). Tõsisemas laadis esietendus Märta Tikkaneni „Sajandi armastuslugu” monolavastusena (1984) kaks aastat enne Ülev Aaloe tõlke ilmumist trükis. Lasteteatri vallas sai aga lastemuusikali žanris alguse Hannu Mäkelä „Härra Huu” lavastuste rida (1986).

Teise kolmandiku Soome-repertuaarist moodustasid enamjaolt vana hea klassika uued seaded: Wuolijoe „Niskamäe noorperenaine”, Kallase „Mare ja ta poeg" suurejoonelise vabaõhuvaatemänguna Viljandi lossimägedes, Kivi „Nõmmekingsepad” ning kaks „Seitsme venna” tõlgendust (1981 Jaan Toominga, 1987 Väino Uibo lavastatuna). Lasteteatrit rikastas Yrjö Kokko Jätkusõja ajal kirjutatud muinasjutt „Pessi ja Illuusia” (1982), üks esimesi tõsitraagilisi lavastusi Nukuteatris. Mõned kriitikud pidasid lavastust liigagi süngeks, seda enam, et Rein Agur tõi näitlejad sirmi tagant välja ja laskis riietada Vene sõjaväevormi (Agur 2017: 38).

Nagu öeldud, mõjutasid 1980-ndate repertuaariplaane ka tähtpäevad, mis nõudsid tähistamist: „Kalevala” aasta (1985) ja Kivi 150. sünniaastapäev (1984). Muu hulgas jõudis lavale üks Kivi-aineline kompositsioon: Indrek Kaberi koostatud „Suvisteöö kevadlõkete põledes” (1981), mille aluseks olid Veijo Meri „Aleksis Stenvalli elu” (eesti keeles 1975), Kivi luuletused Debora Vaarandi tõlkes jm. Kuid olulisem on antud ajajärgu Soome-repertuaari viimane kolmandik: lavastused, mis kobarduvad „Kalevala” ja soome-ugri folkloori ümber ning manifesteerivad jõulisemalt või nõrgemini soome-ugri identiteeti (vt lähemalt Epner 2018).

12 Neid on siiski vähe. Aastail 1980-1987 tuli Soomest kolm külalislavastajat ja eestlased tegid Soomes kuus lavastust. Järgmisel, veel lühemal perioodil 1988-1991 need arvud kahekordistusid.

${ }^{13}$ Kavas olid esindatud Juhani Aho, Unto Seppänen, Veikko Antero Koskenniemi, Veikko Huovinen, Pentti Haanpää, Frants H. Nortamo (murdekirjanik Frans Hjalmar Nordling). Neist ainult Huovinen oli varem teatri kaudu tuttav, teiste loomingut oli ilmunud raamatuna. 
Kujutelm eestlasest kui soomeugrilasest levis laiemalt 1970. aastaist peale ning oli seotud autentse, arhailise kultuuripõhja otsingutega, mis oleks vaba võõrastest mõjudest (vt Kaljundi 2018). Soomeugrilus, mida esindasid näiteks Lennart Meri raamatud ja filmid, Kaljo Põllu graafilised lehed, Veljo Tormise muusika, oli koos eesti rahvakultuuriga vastukultuuri allikaks, mis võimaldas rõhutada sõltumatust nõukogulikest identiteedimudelitest (vt Arukask 2018). Selles vaates kuuluvad soomlased ja eestlased koos teiste soome-ugri rahvastega iidsesse kooslusse, mis keelelis-kultuuriliselt erineb indoeuroopa kultuuriareaalist. Kõige puhtamalt avalduvat soomeugrilus rahvapärimuses, folklooris, aga samuti „Kalevalas”, mille Elias Lönnrot koostas suures osas autentsetest, peamiselt Karjalast üles kirjutatud runodest. „Kalevala” võivad mingil määral omaks pidada ka eestlased. August Annisti väidet, et see on läänemeresoome ühiseepos, mis sündinud ühisest muinaskultuurist (Annist 1969: 7), on palju tsiteeritud. Soome ja eesti runol on sama algupära, oma ürgseimates motiivides ulatub see tagasi arktiliste müütide ja šamanismini ehk muinaspõhjamaise kultuurini (Annist 1969: 33). Eesti ja soome identiteedi ühisosa laseb oletada, et „Kalevalal” ja folklooril põhinevad teatrilavastused tegelesid ühtaegu eesti rahvusidentiteedi kinnitamise ja uuendamisega.

Kaks suurejoonelist ja vaatemängulist lavastust valmis Tallinna Draamateatris soome külalislavastajate käe all: Paavo Liski lavastas „Kalevala” $(1980)^{14}$ ja Markku Savolainen Aleksis Kivi tragöödia „Kullervo” Lauri Sipari tekstiversioonis (1985). „Kalevala” oli üles ehitatud eepilise teatri laadis mänguna, kus külaelanikud võtavad endale „Kalevala” kangelaste rolle ja tegevust suunavad mängujuhid. See võttestik lähendas lavastust folkloorsele rahvateatrile. Arvustustes rõhutati eepose soomeugrilist ühisalust ja mõju „Kalevipojale”, st näidati, et soome eepos on eestlastelegi „oma”, isegi kui teatrilaad tundub võõras. Soome ajakirjandusele antud intervjuus ütles ka Paavo Liski, et kui tema lavastus Oulus oli soome „Kalevala”, siis Tallinna oma on soomeugri „Kalevala”, ning Lemminkäise osatäitja Ago-Endrik Kerge kinnitas samas, et lavastus pani teda oma eestlust uue tõsidusega kaaluma (Liski 1980: 57-59). Kivi „Kullervo” ärgitas aga vaidlusi tragöödia teemal. Kriitikas kõlas arvamus, et lavastus, mis „toetub klassiku autoriteedile ja tragöödiažanri prestiižile ning apelleerib hõimutunnetele" (Heinapuu 1991: 19), on põhjamaise tragöödia vaimuga vastuolus, ning Arvo Valton (1985) leidis, et kreekaliku tragöödia žanrireeglid on Kivi pigem seganud ning juhtinud eemale soomeugrilisest elukäsitusest.

Päris teadlikult tegeldi soome-ugri identiteedi konstrueerimisega samal ajal Ugala teatris, mida juhtis Jaan Tooming ja kus folklooripõhiseid lavastusi tegid noor lavastaja Priit Pedajas ning muusik ja hõimuliikumise aktivist Mikk Sarv. On loomulik, et lavastamiseks valiti ka sobilikke soome materjale. Niisuguseid lavastusi esietendus tol kümnendil neli. Eeskätt lastele oli suunatud Pedajase kompositsioon „Soome muinasjutud” (1981), kus pajatati ja mängiti muu hulgas „Kalevala” motiive kasutavaid muinasjutte. Pedajas

14 „Kalevala” on hea näide mitmepoolsest hõimurahvastevahelisest kultuuriülekandest. Aluseks oli ungarlaste Károly Kazimiri ja Guyla Ortutay dramatiseering, mis esietendus Budapesti Thália teatris. Sellega anti külalisetendus Helsingis 1969, Paavo Liski kasutas seejärel sama dramatiseeringut „Kalevala” lavastuses, millega avati 1972 Oulu Linnateater. Ungarlaste „Kalevala” käis 1972. aastal külas ka Tallinnas. 
lavastas ka Eino Leino ajaloolise draama „Lalli” (kirjutatud 1907, varem eesti teatris esitamata) pealkirjaga „Mere keskel on mees” (1984), tõlkija ja muusikaline kujundaja oli Mikk Sarv. Leino draama kujutab soomlaste ristiusustamise aega XII sajandil ja põhineb legendil talupoeg Lallist, kes tapab järvejääl piiskop Henriku. Kauge minevik tegevusajana põhjendas ehtsate runode (sh saami motiivide) sissepõimimist ja mansi karupeiete viisi kasutamist muusikalise kujunduse peamotiivina. Mikk Sarv ja Kristi Teemusk aga laulsid, retsiteerisid ja deklameerisid Eino Leino luulet kompositsioonis „Päikese õpetus (Helkalaulud)” (1983), mida raamisid kaks saami joigu.

Ugalas pakuti ka omaenda versiooni „Kalevalast”: 1985 esietendus „Kalevala kangelaslood" (Marju Sarve tekstikompositsioon, Mikk Sarve lavastus). Selle fookuses polnud niivõrd Lönnroti eepos kui müüt Sampost. Tekst, mis järgis sündmusi Väinämöise sünnist kuni Sampo purunemiseni, koostati eepose kümnest runost ning juurde liideti värsse kogust „Kanteletar” ja rahvalauludest. Kombineeriti eri põhjarahvaste pärimuskultuuri elemente, rõhk langes rahvalaulule ja muusikale võimalikult autentses esituses ning „Kalevala" käsitati hõimurahvaste ühiseeposena, põhjamaa põlisrahvaste maailmataju ja -mõistmise väljendusena. Lavastus kuulutas jõuliselt soome-ugri või isegi ehk boreaalset identiteeti. Need ja mõned teised folkloorilavastused panid aluse nn pärimusteatri suunale eesti teatris, mida jäi kandma mõte eestlaste kultuurilisest sugulusest soome-ugri ning põhjarahvastega, kes erinevad teravalt indoeurooplastest.

\section{Pisut pöördeajast}

See lühike periood 1988. aastast hooajani 1991/92, s.o Eesti iseseisvuse taastamiseni, nõuab eraldi vaatlemist, sest repertuaaripoliitika muutus põhimõtteliselt: lõppes tekstide tsenseerimine, enam polnud tarvis Moskvast lääne uue dramaturgia jaoks luba taotleda. Teatripilti mõjutasid piiride avanemine läände ning uute väiketeatrite teke, aga ka publikulangus, mis kiirenes kümnendivahetusel. Suuremate teatrite repertuaaripilt näitab järsku pööret: aastail 1988-1993 oli lääne dramaturgia osakaal uuslavastustest 61\% (rõhuga kaasaegsel kirjandusel), samal ajal kui vene dramaturgia taandus 6\%-le (Rebane 2002: 45). Soome dramaturgia lavastustest sõnateatris (kokku 5) ei põhine ükski vanal klassikal. ${ }^{15}$ Uues dramatiseeringus mängiti Huovineni „Havukka-aho mõtlejat” (pealkirjaga „Värviliste mõtete suvi”, 1989). Kui see lavastus oli poliitiliselt neutraalne, siis teised tekstid kandsid või said laval poliitilisi (kaas)tähendusi.

Arto Paasilinna 1987. aastal eesti keeles ilmunud jutustuse „Ulguv mölder” (ilmus Soomes 1981) dramatiseeris ja lavastas Pärnu teatris koreograaf Mai Murdmaa (1988). Ulguva möldri Huttuneni kui teisitiolija hullumajja panek ja külakogukonnast väljatõukamine lubas tõmmata paralleele nõukogude ajaga, mil dissidente taga kiusati. Päevakohaste soome näidenditega sisustas pöördeaja repertuaari Vanemuise uus juht Ago-Endrik Kerge. Erkki

\footnotetext{
${ }^{15}$ See-eest sai klassikat näha muusika- ja tantsuteatris: Vanemuises esietendusid Eero Ojaneni ballett „Seitse venda” Kivi romaani järgi (1988) ja Ilkka Kuusisto ooper „Mehe küljeluu" Jotuni komöödia põhjal (1990).
} 
Mäkineni „Viimse valsi Viiburis” (1989, Soome esmalavastus 1985) valis tõenäoliselt külalislavastaja Rauli Lehtonen. Näidendi sündmused toimuvad 1944. aastal Viiburis, Vene vägedega peetud lahingu aegu, mis võis eestlastes tekitada äratundmisefekti. Ajalukku viis ka Ilpo Tuomarila „Hurmav Hermann Göring” (1990, Soomes esietendus vaid kümme kuud varem), mis näitas SS-lasi läbi koomikaprisma. Ja 1989. aasta kevadel toimus Eestis taas ühe soome näidendi maailmaesietendus. Tauno Yliruusi 1960-ndate lõpus kirjutatud poliitiline komöödia „Magamistoad” kujutab Brežnevite ja Dubčekite abielupaaride koduste dialoogide vormis Tšehhoslovakkia sündmusi 1968. aastal. Soomes ei lavastatud seda arvatavasti enesetsensuuri tõttu, et mitte ärritada Nõukogude Liidu võime. Tollases Eestis mõjus poliitiline farss aga vabastavalt; see oli aeg, kui eestlased juba julgesid ja oskasid vanade hirmude üle naerda (Tonts 1989). Ajaloolisi teemasid käsitlevad soome näidendid aitasid kaasa mineviku ümbermõtestamisele mittenõukogulikul alusel ning omandasid antud ajastu kontekstis poliitilisi tähendusi.

\section{Kokkuvõtteid. Kaanonist}

Nõukogude võimu 47 aasta jooksul (sügisest 1944 kuni sügiseni 1991) tuli eesti kutselistes teatrites lavale poolsada soome dramaturgia lavastust, mille aluseks on umbes 40 erinevat teksti. Seda ei ole palju, kuid arvestades piiranguid, mida seadis riiklikult kontrollitud ja reguleeritud repertuaaripoliitika, ei ole seda ka liiga vähe. Lavastuste arv kasvas 1980-ndatel sedamööda, kuidas repertuaari koostamise piirangud nõrgenesid.

Repertuaaris domineerisid pikka aega enne Teist maailmasõda kirjutatud teosed. Pidevam kontakt soome kaasaegse kirjandusega sugenes alles 1980-ndate keskpaiku, enne seda oli lavastusi vaid üksikuid. Populaarsemad autorid olid Hella Wuolijoki (12 lavastust) ja Aleksis Kivi (10 lavastust) ning kui lisada Teuvo Pakkala „Parvepoisid” (3), siis andsid need kolm autorit kokku poole kogu nõukogude aja Soome-lavastustest.

Kas need valikud peegeldasid adekvaatselt soome dramaturgia kodumaist kaanonit? Kõigepealt vajab täpsustamist kaanoni mõiste teatris. Kirjanduskaanonit defineerib Tiit Hennoste (1997: 59) kirjandusteoste ja nende autorite kogumina, mis on välja valitud nende kirjandusliku kvaliteedi ja tähtsuse põhjal. On ilmne, et kaanon muutub ajas, kuna muutuvad esteetilised kriteeriumid ja ideoloogilised tegurid. Teatris mängib näidendi või dramatiseeritud proosa kaanonisse võtmisel või sealt väljaarvamisel kaalukat rolli lavastamise lugu. Kaanonit aitab kinnitada või muuta teose korduv lavastamine. Kui aga näidendit lakatakse uuslavastamast, siis taandub see teatrikaanonist, hoolimata kirjanduslikest väärtustest. Peale kriitikute mõjutab teatrikaanonit seega ka publik, sest kui näidendi uuslavastused ei ole piisavalt populaarsed, siis ei ole korduslavastamine eriti tõenäoline. (Wilmer, Koski 2006: 79-80) Soome draamakaanoni neli nurgakivi on Steve E. Wilmeri hinnangul Aleksis Kivi, Minna Canth, Maria Jotuni ja Hella Wuolijoki (pangem tähele, et suisa kolm autorit on naised); neist Wuolijoe tee kaanonisse olevat olnud raske just seetõttu, et populaarsus on olnud kõrgem kui kriitika hinnang (Wilmer, Koski 2006: 81). Soome teatri- ja kirjanduslugudele toetudes saab kindlasti 
kaanonisse lisada Pakkala „Parvepoisid”, Maiju Lassila, Eino Leino jt loomingu. Seda kaanonit vahendasid eesti teatrid nõukogude ajal päris korralikult (tõsi, Jotuni komöödiad olid soome külalislavastajate valik), mis tähendas ka kindla peale minekut, orienteerumist läbiproovitud ja eeldatavalt populaarsele repertuaarile. Suur erand on aga soomlastele tähtis Minna Canth, kelle teoseid võis Eestis näha vaid paaril korral harrastusteatris. Ometi võinuks Canthi sotsiaalselt terav „nördimusrealism” (Laitinen 1994: 191) nõukogude ideoloogiaga valutult sobida. Kuid sotsiaalkriitilist realismi oli eesti teatris niigi palju vene ja nõukogude näidenditena, lisa Soomest ei vajatud, ning ka Canthi naisõiguslik paatos ei olnud Eesti pigem patriarhaalses ühiskondlikus kliimas eriti ligitõmbav, Wuolijoe tugevatest naistest nähtavasti piisas.

Peter Burke toob välja neli põhistrateegiat teise kultuuri elementide vastuvõtul: omaksvõtt, mis võib ulatuda teise kultuuri moodiminekuni (Soome puhul siis fennofiiliani); tagasilükkamine või vastupanu, näiteks kui oma identiteeti defineeritakse opositsiooni kaudu võõrale kultuurile; segregatsioon, mispuhul osa oma kultuuriterritooriumist püütakse välismõjudest vaba hoida; ja adapteerimine ehk oma kultuuriga kohandamine (Burke 2009: 79-82). (Kohandamine leiab õieti alati aset, mistõttu on küsitav selle vaatlemine eraldi strateegiana.) Soome dramaturgia retseptsiooni eesti teatris kontrollis vaadeldud ajal nõukogude ideoloogia, ent tsensuur seda ei tõrjunud (paari erandiga), liiati et valdavalt oli tegemist klassikaga. Samas ei saanud repertuaari kontrollimise tõttu tekkida ka soome dramaturgia buumi, fennofiilsed hoiakud avaldusid vaid piiratult. Mis puudutab segregatsiooni, siis pole teater (kui kultuurisüsteem, mitte üksikud teatriorganisatsioonid) Eestis ${ }^{16}$ pea kunagi olnud ainult omakultuuriline valdkond, vaid otsinud rohkem või vähem mängumaterjali teistest kultuuridest. Valitsevad strateegiad nõukogude ajal olid adapteerimine ja omaksvõtt, seda enam, et kultuurilis-keelelise läheduse tõttu oli tekstide rekontekstualiseerimine ja kohandamine kerge.

Viimane väide nõuab ometi selgitamist, sest eks hakanud pärast Eesti okupeerimist kiiresti suurenema Soome ja Eesti sotsiaalkultuurilise olukorra erinevus, kuni sügava lõhe tekkimiseni stalinismiajal. Ajapikku hakkas lõhe pisut tasanduma, kuid ei kadunud. Teatris see lahknevus aga esile ei tulnud, sest nagu eespoolsest kokkuvõttest ilmneb, (ainu)valitses soome dramaturgia lavastustes minevikku pööratus: eelistati klassikat ning ka uuemad soome tekstid, mida teatrites mängiti, kujutasid peaaegu eranditult minevikku, ajalugu. Kui nõustuda väitega, et hilisnõukogude kultuuri nähtamatuks, kuid määravaks osaks oli nn imaginaarne Lääs - kujutluslik maailm „mujal”, mis eksisteeris sel ajal, kui kontaktid reaalse läänemaailmaga olid väga piiratud (Yurchak 2006: 159, 165) -, siis Eestis konstrueerisid imaginaarset Läänt küll jõuliselt Soome televisioon ning seal näidatavad filmid ja seriaalid, ent teatris aitas soome dramaturgia pigem konstrueerida kujutluslikku „kuldset minevikku", mis sarnasuse alusel toitis eestlaste nostalgiat kadunud aegade järele ja aitas kaasa eestluse hoidmisele. Tekstide soomepärasus, olgu Kivi seitsme venna arhetüüpne soomlus, parvepoisiromantika vm, ei mõjunud liiga võõrana ega takistanud retseptsiooni. Eraldi märkimist väärivad „Kalevalal” ning

\footnotetext{
${ }^{16}$ See pole nii ainult Eestis. Ka Euroopa kohta väidab Jaak Rähesoo, et kõigist kunstidest oli teater algselt „kõige omaalusetum” ning teatri levik andis tunnistust inimeste meelte avanemisest võõrale ning uuele (Rähesoo 2006: 2392).
} 
folklooril põhinevad lavastused hilisnõukogude ajal, 1980. aastatel, mis täitsid uusi, senisest erinevaid ülesandeid - nii nõukogude kui ka Euroopa mudelitest erineva soome-ugri identiteedi konstrueerimist. Neis lavastustes, mis toetasid Eestis tärkavat pärimusteatri suundumust, aktiveeriti too ühine kultuuriline alus, millele toetuvad mõlemad kultuurid.

\section{Arhiiviallikad}

Kunstinõukogu protokoll = RAT Vanemuise kunstinõukogu protokoll 23. I 1961. Vanemuise raamatukogu.

\section{Kirjandus}

Agur, Rein 2017. Avangard ja underground nukukunstis. Vestlus Rein Aguriga. Teater. Muusika. Kino, juuli-august, lk 33-38.

Annist, August 1969. „Kalevala” kui kunstiteos. Tallinn: Eesti Raamat.

Arukask, Madis 2018. Soomeugrilusest eesti rahvuspildis - kas jagatud emotsioon või hägune küsitavus? - Keel ja Kirjandus, nr 1-2, lk 104-117.

Balbat, Maris 1972. Kompromissitu Marina. - Teatrimärkmik 1968/69. Koost M. Balbat, Kadi Vanaveski. Tallinn: Eesti NSV Teatriühing, Eesti Raamat, lk 143-150.

B u rke, Peter 2009. Cultural Hybridity. Cambridge, Malden: Polity Press.

Draamateatrite repertuaarist ja selle parandamise abinõudest. - Sirp ja Vasar 7. IX 1946, lk 1.

Epner, Luule 2015. Teatrite mängukava. - Eesti sõnateater 1965-1985. I. Peatoim Piret Kruuspere. Tallinn: Eesti Muusika- ja Teatriakadeemia lavakunstikool, Eesti Teatriliit, Eesti TA Underi ja Tuglase Kirjanduskeskus, lk 166-207.

E p ner, Luule 2018. „Kalevala” eesti teatris. - Teatrielu 2017. Koost Madli Pesti, Tambet Kaugema. Tallinn: Eesti Teatriliit, Eesti Teatri Agentuur, lk 238-260.

Es pagne, Michel 1999. Les transferts culturels franco-allemands. Paris: Presses Universitaires de France.

Es pagn e, Michel 2013. La notion de transfert culturel. - Revue Sciences/Lettres, nr 1. http://rsl.revues.org/219 (5. IV 2019).

Ha a n, Kalju 1969. Mulluse parima soome näidendi esietendus Draamateatris. Sirp ja Vasar 7. III, lk 4.

H a a n, Kalju, O tt, Urmas 2012. Eesti teater. Nõudmiseni. Tallinn: Eesti Teatri-ja Muusikamuuseum.

He in a p u u, Andres 1991. Kaks Kalevala-aasta lavastust. - Teatrielu 1985. Koost Sirje Endre, Margot Visnap. Tallinn: Eesti Raamat, lk 15-26.

Hen no s te, Tiit 1997. Kaanon. Kaanan. - Vikerkaar, nr 12, lk 59-70.

Ird, Kaarel 1982. Epp Kaidu teatritee. - Epp Kaidu kaasaegsete mälestustes. Koost Oskar Kuningas. Tallinn: Eesti Raamat, lk 29-62.

Kaljundi, Linda 2018. Eestlased kui soomeugrilased. - Vikerkaar, nr 1-2, lk 95-106.

Karja, Sven 2017. Eesti teatrite repertuaari koostamise põhimõtted 1986-2006. - Methis. Studia humaniora Estonica, nr 19, lk 89-111. 
Kask, Karin 1987. Eesti nõukogude teater 1940-1965. Sõnalavastus. Tallinn: Eesti Raamat.

Ka s k, Karin, Vell e r a nd, Lilian 1980. Inimesed teatrisaalis. Tallinn: Perioodika. Kru u s, Oskar 1999. Hella Wuolijoki. Tallinn: Virgela.

Kuldke p p, Mart 2013. The Scandinavian connection in early Estonian nationalism. - Journal of Baltic Studies, kd 44, nr 3, lk 313-338.

Laitinen, Kai 1994. Soome kirjanduse ajalugu. Tlk Piret Saluri. Tallinn: Vagabund.

Le p pik, Helle 2006. Ugala aja lugu. [Viljandi]: Ugala.

Li s ki, Paavo 1980. [Intervjuu.] - Apu, nr 7, 15. II, lk 56-59.

Oles k, Sirje 2005. Uus põlvkond hõimutöös. - Kultuurisild üle Soome lahe. EestiSoome akadeemilised ja kultuurisuhted 1918-1944. Koost S. Olesk. Tartu: Eesti Kirjandusmuuseum, lk 39-52.

Paavolainen, Pentti 1992. Teatteri ja suuri muutto. Ohjelmistot sosiaalisen murroksen osana 1959-1971. Helsinki: Kustannus OY.

Peter s o o, Pille 2005. Kas „teine” on alati negatiivne? - Vikerkaar, nr 10-11, lk 109-117.

Re b a n e, Elo 2002. Teater ja sotsiaalne kontekst. Eesti teater aastatel 1948-1953 ja 1988-1993. Bakalaureusetöö. Tartu Ülikool, teatriteaduse ja kirjandusteooria õppetool.

Re b a ne, Hilve 1976. „Veel on tarvis parvepoisse...” - Edasi 22. VIII.

R äh e s o o, Jaak 2006. Omajuur ja kaleidoskoop. Kaks teatrimudelit. - Akadeemia, nr 11, lk 2391-2406.

Räh e s o o, Jaak 2011. Eesti teater. Ülevaateteos. 1. Tallinn: Eesti Teatriliit.

Rähes o o, Jaak 2015. Ingo Normet. - Eesti sõnateater 1965-1985. I. Peatoim Piret Kruuspere. Tallinn: Eesti Muusika- ja Teatriakadeemia lavakunstikool, Eesti Teatriliit, Eesti TA Underi ja Tuglase Kirjanduskeskus, lk 574-593.

Seppälä, Mikko-Olavi, Tanskanen, Katri (toim) 2010. Suomen teatteri ja draama. Helsinki: Like.

Talts, Leida 2000. Pärnu teatrilugu 1875-1991. [Tallinn: Eesti Raamat].

Teatriuudiseid Soomest. Vestlus Helsingi Rahvateatri dir. Eino Salmelaisega. Teater 1936, nr 8, lk 292-295.

T o b r o, Valdeko 1969. „Põletatud oranž”. - Õhtuleht 12. III.

Tonts, Ülo 1989. Poliitika tegijad ja poliitika ohvrid. - Sirp ja Vasar 9. VI, lk 6.

Türk, Eduard 1964. Sinilindu püüdmas. Teatrimälestusi. Tallinn: Eesti Riiklik Kirjastus.

V alt o n, Arvo 1985. „Kullervo” elukäsitusest. - Looming, nr 5, lk 715-716.

Veski, Kristi 2014. Eesti teatrikontaktid Soomega aastatel 1906-1939. Bakalaureusetöö. Tartu Ülikool, teatriteaduse õppetool. http://hdl.handle. net/10062/42449 (11. X 2019).

Veski mägi, Kaljo-Olev 1996. Nõukogude unelaadne elu. Tsensuur Eesti NSV-s ja tema peremehed. Tallinn: K.-O. Veskimägi.

Viller, Jaak 2015. Teatrisüsteem Nõukogude Eestis. - Eesti sõnateater 19651985. I. Peatoim Piret Kruuspere. Tallinn: Eesti Muusika- ja Teatriakadeemia lavakunstikool, Eesti Teatriliit, Eesti TA Underi ja Tuglase Kirjanduskeskus, lk 31-72.

Wilmer, Steve E., Koski, Pirkko 2006. The Dynamic World of Finnish Theatre. Helsinki: Like. 
Ülevaade Eesti NSV Teatriühingu tegevusest 1969-1972. Materjal Eesti NSV Teatriühingu IV kongressile. Koost Ants Päiel. Tallinn: Eesti Raamat, 1973.

Y u r chak, Alexei 2006. Everything Was Forever, Until It Was No More. The Last Soviet Generation. Princeton-Oxford: Princeton University Press.

Luule Epner (snd 1953), PhD, Tallinna Ülikooli humanitaarteaduste instituudi eesti kirjanduse dotsent (Narva mnt 25, 10120 Tallinn), epner@tlu.ee

\section{Finnish drama in Soviet Estonian theatre}

Keywords: cultural transfer, repertoire, Finnish drama, Soviet Estonian theatre

The article deals with the reception of Finnish plays and adaptations of Finnish novels in the Soviet Estonian theatre (1944-1991), relying on the theory of cultural transfer. It first describes the mechanisms to form and control the theatre repertoire in Soviet Estonia. The productions of Finnish drama are then examined by different periods: Stalinism and the "thaw" - interruption and then the return of Finnish classics to the stage; the late 1960s and the 1970s - first stage productions of Finnish contemporary drama and productions of classics in a modern style; the 1980s - stage productions based on folklore and the epic Kalevala; the period of the restoration of Estonian independence - politically motivated interpretations of Finnish contemporary drama. In general, the repertoire was dominated by classics; the most popular authors were Hella Wuolijoki and Aleksis Kivi. Regular contact with Finnish contemporary literature only occurred in the mid-1980s. The main strategies of reception were acceptance and adaptation. In the Estonian theatre, Finnish dramas helped to construct an imaginary "golden past", which, on the basis of similarity, fed the nostalgia of Estonians for the lost times and contributed to the preservation of Estonianness. In late Soviet Estonia theatrical productions based on Kalevala and folklore acquired an additional mission of building up a Finno-Ugric identity different not only from the Soviet one, but also from IndoEuropean models.

Luule Epner (b. 1953), PhD, Tallinn University, School of Humanities (Narva mnt 25, 10120 Tallinn), Associate Professor of Estonian Literature, epner@tlu.ee 